\title{
LOSS APPORTIONMENT IN GOVERNMENT CONTRACT CASES
}

Courts generally have been reluctant to shift losses arising from difficulty in performing contractual obligations from the performing party to the other contracting party. In a recent Court of Claims case, National Presto Indus., Inc. v. United States, ${ }^{1}$ however, the Government was held liable for half the losses suffered by the promisor as a result of extended production difficulty.

In that case the Ordnance Department of the Army entered into tentative facilities and supply contracts with the plaintiff, National Presto Industries, for the purpose of establishing a plant for producing shells ${ }^{2}$ by an untested method. Ordnance hoped the new method would achieve concentricity without a grinding step. Plaintiff was to propose equipment it needed for production, and Ordnance was to pay for items it agreed were necessary. Ordnance denied plaintiff's proposal for twenty-four plunge grinders, ${ }^{3}$ although Ordnance's representative orally promised to pay for their acquisition if the need became apparent during the course of performance. 4 The parties then entered into a final contract for the production of 180,000 shells to be manufactured by the new process. ${ }^{5}$ Over a protracted period of time plaintiff encountered difficulties trying to mass produce concentric shells without shaving off some steel. It then transferred four lathes from its conventional shell producing plant and attained concentricity in mass production by removing a small amount of steel-less than had to be removed under conventional production methods. When delivery was completed, the Government paid the full contract price as well as the cost of moving the additional equipment. ${ }^{6}$ Plaintiff claimed to have lost more than 700,000 dollars because of the unforeseen delays and difficulties. The

1338 F.2d 99 (Ct. Cl. 1964), cert. denied, 380 U.S. 962 (1965).

2 The "shell" is the projectile part of the ammunition. See Brief for Defendant, p. 11, National Presto Indus., Inc. v. United States, supra note 1.

3 Plunge grinders are "devices mainly used to remove surface imperfections in steel." $338 \mathrm{~F} .2 \mathrm{~d}$ at 101 . The plaintiff's proposed machinery would have cost $\$ 321,000$.

4 This oral promise was not disputed. See Brief for Defendant, p. 53, National Presto Indus., Inc. v. United States, 338 F.2d 99 (Ct. Cl. 1964), cert. denied, 380 U.S. 962 (1965). However, defendant contested plaintiff's allegation that Ordnance promised to be responsible for the consequences of doing without plunge grinders. The court found that plaintiff failed to meet its burden of proof on this point. 338 F.2d at 101 n.1.

5 Prior to this contract, the parties had entered into an agreement for the production of $1,000,000$ shells by the new method. Before any shells were produced, however, the Government terminated the contract along with another for production of shells at another plant by the conventional method. Then a supplemental agreement was entered into, whereby plaintiff was to produce $1,100,000$ shells at either plant for a fixed price. When 800,000 shells had been shipped from the conventional plant, the parties entered the 180,000-shell agreement. Plaintiff agreed to phase out operations at the conventional plant. $I d$. at 102.

6 The Government also authorized plaintiff to purchase automatic lathes, at a cost of $\$ 1,200,000$, to remove steel from the shells in future operations. Finding of Fact No. 48, Petition for Writ of Certiorari, pp. 74-75, United States v. National Presto Indus., Inc., cert. denied, 380 U.S. 962 (1965). 
Court of Claims held that the plaintiff could recover from the Government half the losses attributable to the delay in furnishing adequate equipment.

The majority held that although the Government's denial of National Presto's request for plunge grinders did not result in an implied warranty that production would progress smoothly without turning equipment, ${ }^{7}$ relief for mutual mistake as to the "need for turning equipment . . . [and] the time and work required to establish that need" 8 was appropriate:

To do justice here we need go no further than formulate and apply a rule for cases of mutual mistake in which the contract, properly construed, allocates the specific risk to neither party-and the side from whom relief is sought received a benefit from the extra work of the type it contemplated obtaining from the contract, and would have been willing, if it had known the true facts from the beginning, to bear a substantial part of the additional expenses. ${ }^{9}$

Judge Whitaker, dissenting, would have denied recovery because National Presto undertook to do the work for a fixed sum. Although he conceded that "the result reached by the court in this case would be a fair and just one, if the contract between the parties permitted it," 10 he thought that the fixed sum should be the limit of National Presto's recovery.

The court conceived of its result as an "unprecedented" application of the doctrine of mutual mistake. ${ }^{11}$ Like the related doctrine of frustration, ${ }^{12}$ mutual mistake is a limitation on the general rule that the promisor assumes the risk of nonperformance or difficulty of performance. ${ }^{13}$ The scope of these limitations in the past has been extremely narrow. ${ }^{14}$ The rule has been that contract reformation should be limited to situations in which the written instrument failed to conform to the intentions of the parties-that is, where the actual agreement was imperfectly recorded. ${ }^{15}$

7338 F.2d at 103-06.

8 Id. at 108 .

- Id. at 111-12.

$10 \mathrm{Id}$. at 113 (italicized in part in original).

11 Id. at 111 .

12 Frustration differs from mistake in that the former doctrine excuses performance when a supervening event, rather than discovery of the nonexistence of a fact assumed to exist when the agreement was made, destroys the basis of the parties' bargain. There is no reason for treating the two situations differently. Krell $\mathrm{v}$. Henry, [1903] 2 K.B. 740, 748-49. In each case the circumstances have turned out not to be as the parties reasonably assumed they would be.

13 Columbus Ry., Power \& Light Co. v. City of Columbus, 249 U.S. 399, 412 (1919); Lloyd v. Murphy, $25 \mathrm{Cal}$. $2 \mathrm{~d} 48,54,153$ P.2d 47, 50 (1944); Holmes, The Comaron Law 300 (1881); McTurnan, An Approach to Common Mistake in English Laze, 41 CAN. B. Rev. 1-2 (1963).

14 [I]f a party charge himself with an obligation possible to be performed, he must abide by it unless performance is rendered impossible by an act of God, the law, or the other party. Unforeseen difficulties will not excuse performance. Where parties have made no provision for a dispensation, the terms of the contract must prevail.

Columbus Ry., Power \& Light Co. v. City of Columbus, supra note 13, at 412 .

15 Day v. United States, 245 U.S. 159 (1917); Maryland Cas. Co. v. United States, 169 F.2d 102 (8th Cir. 1948); 3 Cormin, Contracts \$ 614 (2d ed. 1960); 5 Williston, Contracts $\$ \$ 1547-49$ (rev. ed. 1937); Restatement, Contracts $\S 504$ (1932). 
Rescission ${ }^{16}$ is the traditional remedy where the parties would not have entered into the contract but for a mutual mistake of underlying fact, ${ }^{17}$ or where an unforeseen and reasonably unforeseeable event makes impossible or extremely difficult the performance of one of the parties. ${ }^{18}$ Of course, in National Presto rescission was impossible because production had been completed and the shells delivered.

Although the court placed its decision on mutual mistake, the majority seems to have had difficulty at times in defining precisely the unforeseen circumstance that led to judgment for National Presto. For instance, in finding that the Government benefited from National Presto's protracted testing, the majority said that the Government wanted to discover by means of the contract whether, without turning equipment, it could mass produce shells effectively by the new process. ${ }^{19}$ This construction implies that at the time of the contract at least one party, the Government, was aware of the danger that turning equipment might be needed. Furthermore, in urging a finding of implied warranty, National Presto argued that it "foresaw from the beginning that it would still be necessary, even under the new process, to remove steel from the shells through the use of turning equipment . . ."20 The court was forced to find that

plaintiff has over-stressed its own knowledge during the precontract stage. The truth, as we see it, is that neither side had the knowledge plaintiff now attributes to itself; plaintiff wanted the plunge grinders for insurance but both parties were under the misapprehension that, given proper engineering, the new process could be utilized without any turning step. ${ }^{21}$

Although the court characterized the mistake of the parties as "the need for turning equipment . . . [and] the time and work required to establish that need," 22 at one point it conceded that

possibly . . plaintiff may have bet that turning equipment would not be needed, but we do not think it bet as to the time and effort which would be necessary to determine that fact. . . . $[B]$ oth sides seemed to believe that such a need would be speedily shown or disproved. ${ }^{23}$

16 "Annulling or abrogation or unmaking of contract and the placing of the parties to it in status quo." BLACK, LAW DICrIONARY 1472 (4th ed. 1951).

17 Sherwood v. Walker, 66 Mich. 568, 33 N.W. 919 (1887); Board of Educ. of Sevier School Dist. v. Board of Educ. of Piute School Dist., 85 Utah 276, 39 P.2d 340 (1934); Griffith v. Brymer, [1903] 19 T.L.R. 434 (K.B.) ; REsTatement, CoNTRACTS $\$ 502$ (1932). A contract may be rescinded for mutual mistake even though executed, where the parties may be returned to the status quo. Peace River Phosphate Mining Co. v. Thomas A. Green, Inc., 102 Fla. 370, 135 So. 828 (1931) (deed for land other than that intended to be conveyed).

18 The Texas Co. v. Hogarth Shipping Co., 256 U.S. 619 (1921) ; The Kronprinzessin Cecilie Case, 244 U.S. 12 (1917); Alvino v. Carraccio, 400 ' Pa. 477, 162 A.2d 358 (1960) ; Fibrosa Spolka Akcyjna v. Fairbairn Lawson Combe Barbour, Ltd., [1943] A.C.' 32 (1942) ; Restatement, Contracts $\$ \$ 456,457$ (1932).

$19338 \mathrm{~F} .2 \mathrm{~d}$ at $111 \mathrm{n} .21$.

$20 I d$. at 103.

21 Id. at 108.

22 Ibid.

23 Id. at 109. 
That distinction seems crucial to the finding of mutual mistake. Apparently the plaintiff had sporadic success in achieving concentricity in mass production until lathes were introduced, and only a long period of uncertain results revealed the need for lathes. Both parties might reasonably have thought the need would be apparent from the outset of production. As a foundation for its finding that the parties thought the need for lathes would be discovered speedily, the court specifically emphasized the novelty of the process, the relative equality of the parties' expertise, and the large loss suffered by plaintiff in relation to the contract price. ${ }^{24}$

In addition to discussing mutual mistake, the court justified its result on another theory. It pointed out that the relationship of the parties gave rise to something more like a "joint enterprise" than a "performance contract." 25 The contractor was to "undertake the study and experimentation, then suggest the procedures to be used, and finally carry out the experiment." 26 The Government approved or disapproved of the contractor's proposals, and thus participated in the setting up of production methods. ${ }^{27}$ Because of the equality of expertise and the joint establishment of the production system, the court said that it would have been unreasonable of the Government to expect the contractor to guarantee the production system. ${ }^{28}$ The statement by the court that the Government benefited from the protracted period of testing ${ }^{29}$ may have been another way of stating that the Government was keenly interested in the method used and was partly responsible for its defects, having helped to set it up. ${ }^{30}$

The court's difficulty in applying the mutual mistake doctrine along with its use of the "joint enterprise" rationale seems to indicate that its primary concern was in reaching a fair result. Contrary to the court's statement, ${ }^{31}$ however, its flexible approach was not entirely without precedent. Some legislatures and courts have provided flexible remedies in mistake and frustration cases where termination of the contractual obligations may be difficult or undesirable. An example of legislative concern is a Georgia statute which grants courts the power to reform contracts for mutual mistake and to rescind on the ground of mistake of one party only. ${ }^{32}$ The power is to be "exercised with caution, and to justify it the evidence shall be clear, unequivocal, and decisive as to the mistake." ${ }^{33}$ An English statute ${ }^{34}$ also gives courts broad powers in cases where contracts

24 Id. at 112 n.22.

25 Id. at 109.

26 Ibid.

27 Where the Government alone promulgates specifications which turn out to be faulty, it is fully responsible for resulting production difficulty. R. M. Hollinshead Corp. v. United States, 124 Ct. Cl. 681, 111 F. Supp. 285 (1953).

28338 F.2d at 109 .

29 See id. at 110-11 \& n.21.

30 The court could not have meant that one party benefits whenever the other party does work it had not contemplated would be necessary. Such a rule would lead to recovery every time a contractor made less profit than he thought he would make.

31338 F.2d at 111.

32 GA. CODE ANN. \& 37-207 (1962).

33 GA. CODE ANN. \$37-202 (1962).

34 The Law Reform (Frustrated Contracts) Act, 1943, 6 \& 7 Geo. 6, c. 40, §1. 
are rescinded to make adjustments for expenses incurred and benefits received by the parties. Courts, too, have developed liberal remedies. In Patch v. Solar Corp..$^{35}$ a clause in an exclusive patent license for the production of washing machines provided for the termination of the license if royalties fell below a certain amount. This part of the contract was held ineffective during the period of a wartime government ban on the production of washing machines. In effect the court read an exception into the termination clause.

Legal writers have advocated the flexible approach which allows courts to provide remedies other than complete termination of the contract. Under one plan courts would use the "gap filling" 36 technique, supplementing contracts with clauses to which the parties would have agreed had they foreseen the risk of changed circumstances. ${ }^{37}$ Professor Corbin is in accord:

When an actually unforeseen event has caused a promised performance to be impossible or increased or decreased its cost or value, and the risks involved can not be shown by a process of factual "interpretation" to have been allocated by the parties themselves, the court must determine their allocation in accordance with the opinions of men in general, as evidenced by business practices and social mores. . . . A party may reasonably be required to pay a fair share of expenditures incurred by the other in the course of his performance, insofar as those expenditures are now a net loss. ${ }^{38}$

It may occasionally be proper for a court to fashion such a flexible remedy. This is particularly so in contract actions against the United States. In such actions, the Court of Claims ${ }^{39}$ applies federal law. ${ }^{40}$ Since, as a result of the decision in Erie R.R. v. Tompkins, ${ }^{41}$ there is little governing precedent in federal contract law, the court seems to have the capacity to fashion new doctrine when necessary to provide just results. ${ }^{42}$

35149 F.2d 558 (7th Cir.), cert. denied, 326 U.S. 741 (1945).

36 The term is from Smit, Frustration of Contract: $A$ Comparative Attempt at Consolidation, 58 CoLUM. L. REv. 287, 293 (1958).

37 Id. at 296, 314; Comment, 59 MrCH. L. REv. 98, 118-19 (1960). Smit points out that the gap filling technique is used in several European countries and may be coming into vogue in others.

38 Corbin, Frustration of Contract in the United States of Anerica, 29 J. Comp. LEG. \& INT'L L. (3d ser.) pts. III \& IV, 1, 8 (1947).

39 The Court of Claims has exclusive jurisdiction over contract claims against the United States when the amount in controversy exceeds $\$ 10,000$, and concurrent jurisdiction with the district courts when the claim is $\$ 10,000$ or less. 28 U.S.C. $\S \S 1346,1491$ (1964).

40 United States v. County of Allegheny, 322 U.S. 174, 183 (1944); Baggett Transp. Co. v. United States, 319 F.2d 864, 868 (Ct. Cl. 1963).

41304 U.S. 64 (1938).

42 The court occasionally has been quite liberal in providing relief in suits against the Government after the contract promises have been executed. E.g., Dillon v. United States, 140 Ct. Cl. 508, 156 F. Supp. 719 (1957) (severe drought in area of delivery point; promisor in supply contract for hay held entitled to recover costs of purchasing hay at insistence of contracting officer from places clearly beyond the area in the contemplation of the parties when the contract was made); Peter Kiewit Sons v. United States, $109 \mathrm{Ct}$. Cl. 517, 74 F. Supp. 165 (1947) (Government varied contract 
This is especially appropriate where standard contracts are involved. Although the majority never suggested that such contracts should be treated any differently from contracts between private parties, at least one consideration indicates that more flexible remedies may be desirable.

This circumstance is the requirement that certain clauses, favorable to the Government, be included in all Department of Defense contracts. One mandatory clause under the Armed Forces Procurement Regulations, the changes clause, ${ }^{43}$ permits the contracting officer ${ }^{44}$ to make changes, within the "general scope" of the contract, in drawings, designs, or specifications, method of shipment or packing, and place of delivery. The clause provides that the contractor may request the contracting officer to make an equitable adjustment in contract price or delivery schedule, or both, but that he may not decline to proceed under the amended contract.

If the contractor fails to obtain satisfactory relief from the contracting officer, he is referred to a second obligatory clause, the disputes clause, ${ }^{45}$ which gives him a right to appeal determinations initially made by the contracting officer to the head of the contracting agency or his representative. $^{46}$ This second intra-agency determination of fact is unassailable "unless . . . not supported by substantial evidence." ${ }^{47}$

A third required clause authorizes the contracting officer to terminate the contract whenever he "shall determine that such termination is in the

but stayed within broad specifications clause; contractor stated cause of action for lost profits) ; Harrison Eng'r \& Constr. Corp. v. United States, $107 \mathrm{Ct}$. Cl. 205, 68 F. Supp. 350 (1946) (release reformed although plaintiff "somewhat negligent") ; Virginia Eng'r Co. v. United States, $101 \mathrm{Ct}$. Cl. 516 (1944) (contractor recovered added cost of performance after he "negligently" relied on the Government's "negligent" misrepresentation of the nature of a building site). The results in the Harrison and Virginia cases seem wrong if the plaintiffs were actually negligent.

4332 C.F.R. \$7.103-2 (1965). The present regulation is substantially the same as that in effect when the contract in National Presto was made. See 15 Fed. Reg. 8044 (1950), amending 14 Fed. Reg. 5075 (1949).

44 'The term 'Contracting Officer' means the person executing this contract on behalf of the Government, and any other officer or civilian employee who is a properly designated Contracting Officer ..." 32 C.F.R. \$7.103-1(b) (1965). The definition is identical with that in 15 Fed. Reg. 8044 (1950).

4532 C.F.R. $\$ 7.103-12$ (1965). The present regulation substantially carries forward 19 Fed. Reg. 5887 (1954) and 17 Fed. Reg. 9856 (1952).

46 This representative is the Armed Services Board of Contract Appeals. 27 Fed. Reg. 3170 (1962) (charter consolidating boards of the separate services). While the Board was designed to provide an impartial forum, its members are appointed by the Assistant Secretary of Defense (Installations and Logistics) and the assistant secretaries of the military departments responsible for procurement. Ibid.

47 Wunderlich Act, 68 Stat. 81 (1954), 41 U.S.C. $\$ 321$ (1964); 32 C.F.R. \$7.103-12(a) (1965). The language is the same as 19 Fed. Reg. 5887 (1954) and 17 Fed. Reg. 9856 (1952). The complete clause is: "unless determined by a court of competent jurisdiction to have been fraudulent, or capricious, or arbitrary, or so grossly erroneous as necessarily to imply bad faith, or not supported by substantial evidence." 32 C.F.R. \$ 7.103-12(a) (1965). It seems reasonable to assume that the operative phrase is "substantial evidence."

The current disputes clause provides that "nothing in this contract shall be construed as making final the decision of any administrative official, representative, or board on a question of law." 32 C.F.R. $\$ 7.103-12$ (b) (1965). Since the distinction between a question of fact and one of law may become tenuous in a contract case, the scope of judicial review of an administrative finding may actually be quite broad. 
best interests of the Government." 48 The contractor must submit a termination claim to the contracting officer. ${ }^{49}$ The two then negotiate regarding the amounts to be paid to the contractor because of the termination, "which . . . may include a reasonable allowance for profit on work done." "50 If they fail to agree, the contracting officer is to reimburse the contractor for his costs and pay him up to a set percentage of the costs as profit. ${ }^{51}$ Again, the contractor has the right of appeal under the disputes clause. ${ }^{52}$

A fourth clause is required in Department of Defense contracts under the Renegotiation Act of $1951 . .^{53}$ Although within the confines of conscionability there is no limit to the amount of profit a contractor can reap in a private contract, this is not true of contractors who make agreements with the Department of Defense. Under the Renegotiation Act, these contractors must agree to renegotiate the contract if the Renegotiation Board finds that profits have become "excessive." 54 The act applies when aggregate amounts received or accrued during a fiscal year from contracts with the specified goverment departments exceed one million dollars. ${ }^{55}$ If the Board and the contractor are unable to agree on the amount of excessive profits, the Board is empowered to determine the amount. ${ }^{56}$ The act thus subjects the contractor to the possibility that his "fixed price" will be reduced under a vague standard. ${ }^{57}$ A contractor who wishes to contest the

4832 C.F.R. $\$ 8.701$ (a) (a) (1965) (incorporated by 32 C.F.R. \$7.103-21 (1965)). The provision in effect during the time of the National Presto case was 17 Fed. Reg. 1808 (1952).

4932 C.F.R. $\$ 8.701$ (a) (c) (1965).

5032 C.F.R. $\$ 8.701$ (a) (d) (1965).

5132 C.F.R. $\$ 8.701$ (a) (e) (1965).

5232 C.F.R. $\$ 8.701$ (a) (g) (1965).

5365 Stat. 7 (1951), as amended, 50 U.S.C. App. $\$ \$ 1211-24$ (1964).

5465 Stat. 11-12 (1951), 50 U.S.C. APP. \$1214 (1958).

5565 Stat. 16 (1951), as amended, 50 U.S.C. APP. §1215(f) (1) (1964). National Presto's shell production between June 30, 1954 and September, 1956 led to receipts of more than $\$ 5,000,000$. See 338 F.2d at 102-03. It is probable that this production was not exempt from the Renegotiation Act for lack of a "direct and immediate" connection with national defense, as provided by 65 Stat. 17-18 (1951), 50 U.S.C. App. \$1216(a) (6) (1964).

5665 Stat. 12 (1951), as amended, 50 U.S.C. APP. $\$ 1215$ (a) (1964).

57 See 65 Stat. 9 (1951), 50 U.S.C. APP. $\$ 1213(\mathrm{e})$ (1964):

The term "excessive profits" means the portion of the profits derived from contracts with [the Department of Defense and other specified departments] . . . which is determined in accordance with this title to be excessive. In determining excessive profits favorable recognition must be given to the efficiency of the contractor or subcontractor, with particular regard to attainment of quantity and quality production, reduction of costs, and economy in the use of materials, facilities, and manpower; and in addition, there shall be taken into consideration the following factors:

(1) Reasonableness of costs and profits, with particular regard to volume of production, normal earnings, and comparison of war and peacetime products;

(2) The net worth, with particular regard to the amount and source of public and private capital employed;

(3) Extent of risk assumed, including the risk incident to reasonable pricing policies; 
Board's finding may obtain review de novo in the Tax Court, ${ }^{58}$ but he will find that the burden of proving error is placed upon him.59

Each clause tends to make the rights and expectations of the contractor more indefinite and more subject to the discretion of the promisee.60 Indeed, it is possible that such clauses would render a private party contract void as too indefinite. ${ }^{61}$ It is arguable that the Renegotiation Act imposes a one sided bargain on the contractor unless the Government is made to bear some of his losses if they become "excessive." But even if the existence of the mandatory clauses does not require special treatment of government contract disputes in a particular case, it at least lends added support to the Court of Claims' provision of flexible remedies.

It does not necessarily follow that in every case involving mandatory clauses, the losses should be shared. Courts generally should hesitate to reapportion losses in executed contracts. ${ }^{62}$ Where there is evidence that the parties intended to place the risk of unforeseen developments upon one or the other, or where the contractor's losses are not of overwhelming proportions, it would seem wise to let the loss remain where it fell. The promisee's execution of his promise is itself evidence that both parties expected him to take the risk of loss from performance. The National Presto case is unusual, however, in that the plaintiff was attempting to perfect an untried process, and the difficulty in determining the necessity for additional equipment was not reasonably foreseeable. At no one stage in the course of perfection could a court have rescinded the contract, because at every stage the Government could have argued persuasively that success was imminent. Where, as in National Presto, losses are extreme and the parties appear to have been jointly responsible for them, it is reasonable to provide the flexible remedy of loss apportionment.

(4) Nature and extent of contribution to the defense effort, including inventive and developmental contribution and cooperation with the Government and other contractors in supplying technical assistance;

(5) Character of business, including source and nature of materials, complexity of manufacturing technique, character and extent of subcontracting, and rate of turn-over;

(6) Such other factors the consideration of which the public interest and fair and equitable dealing may require, which factors shall be published in the regulations of the Board from time to time as adopted.

6865 Stat. 21-22 (1951), as amended, 28 U.S.C. App. $\$ 1218$ (1964).

59 Boeing Co. v. Renegotiation Board, 325 F.2d 885 (9th Cir. 1963) ; Golbert v. Renegotiation Board, 254 F.2d 416 (2d Cir. 1958) (per curiam).

60 The danger inherent in this condition may be remote in view of the apparently lenient attitude of the Court of Claims. See cases cited note 42 supra.

${ }^{61}$ See Note, Formal and Doctrinal Differences Between Government and Private Contracts, 1 SaN Diego L. Rev. 88, 90, 96 (1964).

Since these clauses cannot be bargained out of the contract, there should be no different treatment for large contractors. For discussion of the problem of contracts in which the Government has forced the private contractor to assume the risk of loss, see generally Cuneo \& Crowell, Impossibility of Performance-Assumption of Risk or Act of Submission?, 29 LAw \& ContenrP. Prob. 531 (1964); Kessler, Contracts of Adhesion-Some Thoughts About Freedom of Contract, 43 CoLUM. L. REv. 629 (1943).

62 See Ga. Code ANn. §37-202 (1962). 